\title{
Targeting specific nutrient deficiencies in protein- restricted diets: some practical facts in PKU dietary management
}

\author{
Filipa B. Pimentel, Rita C. Alves, M. Teresa Oliva-Teles, Anabela S. G. Costa, Telmo J. R. Fernandes, Manuela F.
} Almeida, Duarte Torres, Cristina Delerue-Matos and M. Beatriz. P. P. Oliveira

\section{ABSTRACT}

Among aminoacidopathies, phenylketonuria (PKU) is the most prevalent one. Early diagnosis in the neo- natal period with a prompt nutritional therapy (low natural-protein and phenylalanine diet, supplemented with phenylalanine-free amino acid mixtures and special lowprotein foods) remains the mainstay of the treatment. Data considering nutrient contents of cooked dishes is lacking. In this study, fourteen dishes specifically prepared for PKU individuals were analysed, regarding the lipid profile and iron and zinc con- tents. These dishes are poor sources of essential nutrients like Fe, $\mathrm{Zn}$ or $n-3$ fatty acids, reinforcing the need for adequate supplementation to cover individual patients' needs. This study can contribute to a more accurate adjustment of PKU diets and supplementation in order to prevent eventual nutritional deficiencies. This study contributes to a better understanding of nutrient intake from PKU patients' meals, showing the need for dietary supplementation.

\section{Introduction}

Protein restricted diets are essential to treat several inherited metabolic disorders, such as aminoacidopathies - phenylketonuria (PKU)/hyperphenylalaninemia, type I tyrosinemia (type I and II), leucinose, type I citrullinemia, argininosuccinic aciduria, hyperargininemia, classical homocystinuria, and hypermethioninemia; and organic acidurias - propionic aciduria, methylmalonic aciduria, isovaleric aciduria, type I glutaric aciduria, or 3-methylcrotonylglycinuria.

Among inherited amino acid metabolic disorders, PKU (OMIM 261600) is the most prevalent one. ${ }^{1}$ It is estimated that the overall prevalence of PKU in Europe and the United States is about 1 in 10000 live births. ${ }^{2}$

For more than sixty years, early nutritional intervention and diet therapy have been the basis of the treatment for the great majority of PKU diagnosed individuals., ${ }^{3,4}$ The dietary management intends, first of all, to maintain phenylalanine (Phe) blood levels within safe limits in order to prevent mental retardation and ensure normal growth and a normal and healthy life through adulthood., ${ }^{4,5}$ High blood Phe concentrations are neurotoxic, as this is known to inhibit the transport of free Lamino acids, required for protein and neurotransmitters synthesis. ${ }^{4}$ Most patients require a natural-protein-restricted diet, which allows the reduction of Phe intake, still ensuring the contribution of some Phe to guarantee normal protein anabolism. ${ }^{5-7}$ According to patients' tolerance, protein richfoods are slightly to strictly restricted. Therefore, meat, fish, eggs, standard bread, dairy products, nuts, seeds and leguminous crops are generally forbidden foods. Protein and essential amino acids intake is basically assured Phe-free amino acids mixtures. Energy needs are met by consuming controlled amounts of low natural protein foods (fruits and vegetables) and special low-protein foods (flour, bread, pasta, biscuits, milk substitutes, cheese substitutes, egg substitutes, soups, and candies, among others), resembling a vegan-like food pattern. $^{7-9}$

As a result of restricting high protein animal-derived foods, these patients are likely to ingest small amounts of essential 
fatty acids and some micronutrients, such as vitamins A, C, $\mathrm{D}$ and $\mathrm{E}$, vitamins $\mathrm{B}_{2}, \mathrm{~B}_{6}$ and $\mathrm{B}_{12}$, and folates, as well as selenium, iron, zinc and calcium. ${ }^{5,7,10-13}$ This is particularly important when planning the diet in a long-term perspective. Most of the existing guidelines in PKU dietary management focus on childhood. ${ }^{13}$ The main concerns have been focused on optimizing the growth and nutritional status of PKU individuals, ensure an optimal compliance of the diet and improve their quality of life. ${ }^{4}$ Ultimately, the treatment should allow PKU patients to achieve an optimal cognitive and psychosocial development and well-being throughout life. Therefore, it is agreed that treatment and follow-up of PKU patients is for life and, based on that, special attention should be given to specific nutrient supplementation in long-term dietary counseling. ${ }^{4,14,15}$ As described by Demirkol and colleagues, ${ }^{14}$ the dietary management for this disease is somewhat complex and time-consuming. It also requires knowledge of foods and recipes, cooking skills and cautious food portions control.

Based on this and following our previous studies, ${ }^{16,17}$ we intended to characterize the composition of low protein dishes, selected from a list of recipes specifically proposed for
PKU patients, regarding the fatty acids profile and tocopherols, tocotrienols, iron and zinc contents, nutrients for which these individuals may be at risk.

\section{Results and discussion}

Patients with PKU need to follow a low-protein diet, but still healthily balanced. ${ }^{16}$ This is a very restrictive vegan-like diet, based on fruits and vegetables, low-protein natural foods, Phefree amino acid mixtures and special low-protein foods, to fulfill their energy needs. The recipes included in this study, described in Table 1, clearly illustrate this feature. As can be observed, vegetables and fruits, followed by dietetic lowprotein products, represent the most significant fraction of the ingredients used to prepare and cook these recipes. The use of significant amounts of different types of fat is also an important aspect to highlight, as this is reflected in the energy contribution and lipid profile of the final product. Spices and aromatic herbs are other features that stand out in many of the recipes, being used to improve the palatability and final

Table 1 List of recipes and cooking methods, category and ingredients of low protein and restricted Phe dishes

\begin{tabular}{|c|c|c|c|}
\hline & Recipe & Category & List of ingredients (weight in $\mathrm{g}$ per $100 \mathrm{~g}$ of edible raw foods) \\
\hline 1 & Green beans soup (boiled) & A & $\begin{array}{l}\text { Water }(55.0 \mathrm{~g}) \text {, green beans }(13.0 \mathrm{~g}) \text {, tomatoes }(9.8 \mathrm{~g}) \text {, onions }(9.5 \mathrm{~g}) \text {, potatoes }(8.8 \mathrm{~g}) \text {, } \\
\text { white cabbage }(2.4 \mathrm{~g}) \text {, potato starch }(0.6 \mathrm{~g}) \text {, carrot }(0.4 \mathrm{~g}) \text {, olive oil }(0.4 \mathrm{~g}) \text {, salt }(0.1 \mathrm{~g}) \text {. }\end{array}$ \\
\hline 2 & Carrot soup (boiled) & A & $\begin{array}{l}\text { Water }(49.8 \mathrm{~g}) \text {, carrots }(32.1 \mathrm{~g}) \text {, onions }(8.1 \mathrm{~g}) \text {, potatoes }(6.1 \mathrm{~g}) \text {, olive oil }(0.9 \mathrm{~g}) \text {, } \\
\text { potato starch }(0.8 \mathrm{~g}) \text {, salt }(0.1 \mathrm{~g}) \text {; low protein bread fried crumbs }{ }^{a} \text { to serve }(2.1 \mathrm{~g}) \text {. }\end{array}$ \\
\hline 3 & $\begin{array}{l}\text { Low protein pasta with spiced } \\
\text { vegetable sauce (stewed) }\end{array}$ & $\mathrm{B}$ & $\begin{array}{l}\text { Onions }(24.5 \mathrm{~g}) \text {, water }(22.7 \mathrm{~g}) \text {, carrots }(16.8 \mathrm{~g}) \text {, fresh mushrooms }(12.2 \mathrm{~g}) \text {, low protein } \\
\text { pasta }^{a}(9.3 \mathrm{~g}) \text {, white cabbage }(6.3 \mathrm{~g}) \text {, olive oil }(4.3 \mathrm{~g}) \text {, margarine }(3.4 \mathrm{~g}) \text {, tomato paste } \\
(0.3 \mathrm{~g}) \text {, spices (saffron, bay leaf and nutmeg, paprika, garlic powder })(0.2 \mathrm{~g}) .\end{array}$ \\
\hline 4 & $\begin{array}{l}\text { Roasted potatoes with vegetables } \\
\text { (roasted) }\end{array}$ & B & $\begin{array}{l}\text { Potatoes }(35.3 \mathrm{~g}) \text {, onions }(20.7 \mathrm{~g}) \text {, carrots }(15.9 \mathrm{~g}) \text {, water }(11.6 \mathrm{~g}) \text {, white wine }(9.2 \mathrm{~g}) \text {, } \\
\text { olive oil }(3.8 \mathrm{~g}) \text {, garlic }(2.7 \mathrm{~g}) \text {, salt }(0.3 \mathrm{~g}) \text {, bay leaf }(0.3 \mathrm{~g}) \text {, parsley leafs }(0.2 \mathrm{~g}) \text {. }\end{array}$ \\
\hline 5 & Potato stuffed (boiled/stewed) & B & $\begin{array}{l}\text { Potatoes }(36.5 \mathrm{~g}) \text {,Water }(33.6 \mathrm{~g}) \text {, tomatoes }(9.8 \mathrm{~g}) \text {, low protein bread }{ }^{a}(6.5 \mathrm{~g}) \text {, mushrooms } \\
(5.8 \mathrm{~g}) \text {, onions }(5.0 \mathrm{~g}) \text {, olive oil }(1.1 \mathrm{~g}) \text {, garlic }(0.9 \mathrm{~g}) \text {, parsley }(0.4 \mathrm{~g}) \text {, corn starch }(0.3 \mathrm{~g}) \text {, } \\
\text { salt }(0.1 \mathrm{~g}) \text {. }\end{array}$ \\
\hline 6 & Vegetables pie (baked) & $\mathrm{B}$ & $\begin{array}{l}\text { Low protein milk substitute }{ }^{a}(28.3 \mathrm{~g}) \text {, water }(17.0 \mathrm{~g}) \text {, potatoes }(17.0 \mathrm{~g}) \text {, artichokes }(12.9 \mathrm{~g}) \text {, } \\
\text { carrots }(11.9 \mathrm{~g}) \text {, Brussels sprouts }(2.3 \mathrm{~g}) \text {, corn starch }(7.1 \mathrm{~g}) \text {, margarine }(2.5 \mathrm{~g}) \text {, low } \\
\text { protein bread dry breadcrumbs }{ }^{a}(0.5 \mathrm{~g}) \text {, spices and salt (nutmeg, paprika, dry parsley) } \\
(0.5 \mathrm{~g}) .\end{array}$ \\
\hline 7 & Onion pie (baked) & B & $\begin{array}{l}\text { Low protein flour }{ }^{a}(24.7 \mathrm{~g}) \text {, low protein milk substitute }{ }^{a}(19.7 \mathrm{~g}) \text {, onions }(15.0 \mathrm{~g}) \text {, } \\
\text { margarine }(12.2 \mathrm{~g}) \text {, water }(10.6 \mathrm{~g}) \text {, carrots }(5.1 \mathrm{~g}) \text {, olives }(4.7 \mathrm{~g}) \text {, mushrooms }(4.3 \mathrm{~g}) \text {, corn } \\
\text { starch }(1.4 \mathrm{~g}) \text {, salt }(0.2 \mathrm{~g}) \text {, garlic powder }(0.1 \mathrm{~g}) \text {, pepper }(0.1 \mathrm{~g}) \text {, olive oil }(0.8 \mathrm{~g}) \text {, corn oil } \\
(0.8 \mathrm{~g}) \text {, dry parsley }(0.3 \mathrm{~g}) \text {. }\end{array}$ \\
\hline 8 & Mushroom croquettes (fried) & $\mathrm{B}$ & $\begin{array}{l}\text { Mushrooms }(31.4 \mathrm{~g}) \text {, low protein milk substitute }{ }^{a}(26.3 \mathrm{~g}) \text {, low protein bread } \text { crumbs }^{a} \\
(15.5 \mathrm{~g}) \text {, olive oil }(11.0 \mathrm{~g}) \text {, water }(5.5 \mathrm{~g}) \text {, corn starch }(5.3 \mathrm{~g}) \text {, margarine }(3.9 \mathrm{~g}) \text {, salt }(0.2 \mathrm{~g}) \text {, } \\
\text { fresh parsley }(0.4 \mathrm{~g}) \text {, nutmeg }(0.1 \mathrm{~g}) \text {, egg substitute }{ }^{a}(0.4 \mathrm{~g}) \text {. }\end{array}$ \\
\hline 9 & Vegetables patties (fried) & B & $\begin{array}{l}\text { Mushrooms }(30.7 \mathrm{~g}) \text {, water }(21.1 \mathrm{~g}) \text {, low protein flour }{ }^{a}(18.7 \mathrm{~g}) \text {, carrots }(9.1 \mathrm{~g}) \text {, corn oil } \\
(5.6 \mathrm{~g}) \text {, olives }(5.3 \mathrm{~g}) \text {, boiled rice }(4.5 \mathrm{~g}) \text {, onions }(3.3 \mathrm{~g}) \text {, white wine }(1.0 \mathrm{~g}) \text {, garlic }(0.5 \mathrm{~g}) \text {, } \\
\text { salt }(0.2 \mathrm{~g}) \text {. }\end{array}$ \\
\hline 10 & Biscuits cake (unprocessed) & $\mathrm{C}$ & $\begin{array}{l}\text { Low protein biscuits }{ }^{a}(37.5 \mathrm{~g}) \text {, sugar }(31.7 \mathrm{~g}) \text {, vegetal margarine }(20.0 \mathrm{~g}) \text {, instant coffee } \\
\text { prepared }(7.7 \mathrm{~g}) \text {, low protein chocolate candy }{ }^{a}(2.9 \mathrm{~g}) \text {, cinnamon }(0.2 \mathrm{~g}) \text {. }\end{array}$ \\
\hline 11 & Pineapple cake (baked) & $\mathrm{C}$ & 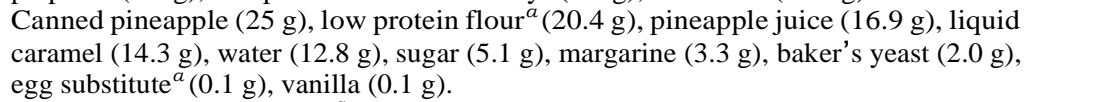 \\
\hline 12 & Sweet vermicelli (boiled) & $\mathrm{C}$ & $\begin{array}{l}\text { Low protein milk substitute }{ }^{a}(38.2 \mathrm{~g}) \text {, water }(47.8 \mathrm{~g}) \text {, lemon zest }(0.6 \mathrm{~g}) \text {, vanilla extract } \\
\left.(0.2 \mathrm{~g}) \text {, cinnamon }(0.2 \mathrm{~g}), \text { low } \text { protein vermicelli }^{a}(9.6 \mathrm{~g}), \text { sugar }^{(} 2.9 \mathrm{~g}\right), \text { egg substitute }^{a} \\
(0.5 \mathrm{~g}) \text {. }\end{array}$ \\
\hline 13 & Low protein bread (baked) & $\mathrm{D}$ & $\begin{array}{l}\text { Water }(47.2 \mathrm{~g}) \text {, low protein flour }{ }^{a}(46.4 \mathrm{~g}) \text {, baker's yeast }(2.6 \mathrm{~g}), \text { margarine }(2.9 \mathrm{~g}) \text {, } \\
\text { salt }(0.9 \mathrm{~g}) .\end{array}$ \\
\hline 14 & $\begin{array}{l}\text { Low protein homemade yogurt } \\
\text { (boiled) }\end{array}$ & $\mathrm{D}$ & $\begin{array}{l}\text { Low protein milk substitute }{ }^{a}(84.4 \mathrm{~g}) \text {, natural yogurt }(9.0 \mathrm{~g}) \text {, corn starch } \quad(5.4 \mathrm{~g}) \text {, } \\
\text { egg substitute }^{a}(1.2 \mathrm{~g}) .\end{array}$ \\
\hline
\end{tabular}

A - soup; B - the main course; C - dessert; D - daily basic foods. ${ }^{a}$ Low protein dietetic products. 
look of the dishes. Typically, this diet provides high intake of carbohydrate rich foods and none or very low intake of animal origin foods, which leads to a low intake of several nutrients such as cholesterol, $\mathrm{Fe}, \mathrm{Se}, \mathrm{Zn}$, and $\mathrm{Ca} .{ }^{4}$ Moreover, fresh fruits and vegetables do not provide some important nutrients like vitamin $\mathrm{B}_{12}$, and others (e.g. $\mathrm{Ca}$ and $\mathrm{Fe}$ ) may present low bioavailability.

In addition, cooking methods can affect foods composition, essentially due to losses and/or incorporation of water and/or fat. Deep-fat frying is an example of that, in which the oil is incorporated into foods during the process. Therefore, the final product somehow exhibits the lipidic profile of the frying oil. Moreover, variation in the composition of foods itself may occur, depending on factors like variety, seasonality, soil type, climate or even procedures related with preparation and cooking. Regarding the latter aspect, precautions were taken in order to accurately replicate home-produced recipes.

The use of seasonings, such as spices and aromatic herb, helps not just to improve the organoleptic aspect, such as taste, odor or visual appearance, but may have particular interest in the PKU particular context, as oxidative stress is a concern in these patients. ${ }^{6}$ In fact, spices and aromatic herbs are known to be rich in several phytochemical compounds with antioxidant activity. ${ }^{18}$

Fats are also an important aspect to highlight in this food pattern context. Besides contributing to accomplishing the individual energy needs, they are a source of fatty acids, cholesterol, and liposoluble vitamins (A, D, E and K).

The type of fatty acids consumed plays an important role in the etiology of several diseases. Saturated fatty acids (SFAs) intake has been associated with coronary heart disease (CHD). In turn, its prevention has been correlated with monounsatu- rated fatty acids (MUFAs) consumption. Also, long chain n-3 polyunsaturated fatty acids (PUFAs) have beneficial effects on human health, regarding neurological functions (especially in children), prevention of CHD and metabolic syndrome, and improvement of immune response. ${ }^{19}$ Western diets are $n-6$ PUFA rich. These compete with $n$-3 PUFA for several physiological processes, being associated with CHD and pro-inflammatory mechanisms. Recent research suggests that an increased $n-3$ FA intake and/or increased $n-3 / n-6$ PUFA ratio in the diet have protecting health effects. ${ }^{20,21}$ Protein-rich foods, and particularly fat fishes, are good sources of PUFA but, as already mentioned, these foods are not allowed in the PKU diet. As a result, patients present lower intakes and lower plasmatic concentrations of PUFA when compared with healthy controls. $^{22}$ The profile of the ingredients used to prepare and cook the recipes (Table 1) was somewhat reflected in the fatty acid profile, which is described in Table 2. Monounsaturated fatty acids (MUFAs), essentially oleic acid (C18:1 $n$-9), were the most representative class in the dishes which contained olive oil as the main fat source or olives as an ingredient.

Recipes containing vegetal margarine, a well known source of SFA, ${ }^{23}$ presented higher relative percentages of these compounds. The main SFA found was palmitic acid (C16:0), followed by stearic acid (C18:0). Recipes containing high quantities of low-protein milk substitutes $(6,7,12$, and 14) also presented greater amounts of stearic acid (C18:0), followed by myristic acid (C14:0), when compared with the remaining ones. Since the low-protein food milk substitute is prepared from cow's milk, which contains a high amount of saturated fat, recipes containing this ingredient presented higher amounts of stearic (C18:0) and myristic (C14:0) acids.

Table 2 Fatty acid composition (relative percentage)

\begin{tabular}{|c|c|c|c|c|c|c|c|c|c|c|c|c|c|c|}
\hline & \multicolumn{14}{|c|}{ Recipes } \\
\hline & 1 & 2 & 3 & 4 & 5 & 6 & 7 & 8 & 9 & 10 & 11 & 12 & 13 & 14 \\
\hline \multicolumn{15}{|l|}{ Fatty acid (\%) } \\
\hline C8:0 & - & - & - & - & - & 0.24 & - & - & - & 0.14 & - & 0.81 & - & 0.81 \\
\hline C10:0 & - & - & - & - & - & 0.54 & - & - & - & 0.12 & - & 2.02 & - & 2.27 \\
\hline C12:0 & 0.12 & 0.10 & - & - & - & 0.95 & 0.43 & 0.10 & - & 1.03 & 0.37 & 2.50 & 0.40 & 2.98 \\
\hline C14:0 & 0.19 & 0.21 & 0.24 & 0.08 & 0.09 & 3.07 & 0.92 & 0.32 & - & 1.05 & 0.70 & 8.17 & 1.15 & 10.15 \\
\hline C15:0 & - & - & - & - & - & 0.27 & - & - & - & - & - & 0.90 & - & 1.04 \\
\hline $\mathrm{C} 16: 0$ & 13.52 & 14.91 & 14.25 & 12.47 & 13.68 & 33.66 & 26.70 & 15.18 & 11.03 & 31.79 & 28.46 & 27.75 & 32.76 & 29.82 \\
\hline C18:0 & 3.64 & 3.78 & 3.78 & 3.10 & 3.27 & 6.93 & 4.22 & 3.24 & 1.76 & 4.67 & 4.36 & 14.83 & 5.21 & 14.36 \\
\hline C16:1 & 0.71 & 0.85 & 0.65 & 1.14 & 1.06 & 0.53 & 0.21 & 1.04 & - & - & - & 1.29 & - & 1.90 \\
\hline $\mathrm{C} 18: 1 n 9 \mathrm{t}$ & - & - & - & 0.13 & 0.17 & 0.63 & - & - & - & - & - & 2.17 & - & 2.47 \\
\hline $\mathrm{C} 18: 1 n 9 \mathrm{c}$ & 55.68 & 54.65 & 64.14 & 66.43 & 62.24 & 31.39 & 39.20 & 64.57 & 32.59 & 36.36 & 35.13 & 21.75 & 32.70 & 21.43 \\
\hline $\mathrm{C} 18: 1$ trans- 11 & 2.21 & 1.93 & 1.48 & 2.32 & 2.16 & 0.76 & 0.91 & 2.22 & 0.79 & 0.73 & 0.75 & 0.72 & 0.74 & 0.81 \\
\hline $\mathrm{C} 18: 2 n 6 \mathrm{cc}$ & 11.2 & 17.51 & 10.91 & 10.60 & 9.26 & 17.78 & 25.61 & 9.14 & 48.55 & 19.69 & 27.57 & 3.81 & 22.36 & 3.28 \\
\hline $\mathrm{C} 18: 3 n 3$ & 0.39 & 1.15 & 0.55 & 0.70 & 0.52 & 0.51 & 0.43 & 0.53 & 0.80 & 0.41 & 0.33 & 0.93 & 0.40 & 0.87 \\
\hline Total $n$-3 PUFA & 0.39 & 1.15 & 0.55 & 0.70 & 0.52 & 0.51 & 0.43 & 0.53 & 0.80 & 0.41 & 0.33 & 0.93 & 0.40 & 0.87 \\
\hline Total $n$-6 PUFA & 11.2 & 17.51 & 10.91 & 10.60 & 9.26 & 17.78 & 25.61 & 9.14 & 48.55 & 19.69 & 27.57 & 3.81 & 22.36 & 3.28 \\
\hline$n-3 / n-6$ & 0.03 & 0.07 & 0.05 & 0.07 & 0.07 & 0.03 & 0.02 & 0.06 & 0.02 & 0.02 & 0.01 & 0.24 & 0.03 & 0.26 \\
\hline
\end{tabular}

Values are the mean relative percentage of triplicate analysis. 1 - green beans soup; 2 - carrot soup; 3 - pasta with vegetables sauce; 4 - roast potatoes with vegetables; 5 - stuffed potato; 6 - vegetables pie; 7 - onion pie; 8 - mushrooms croquettes; 9 - vegetables patties; 10 - biscuits cake; 11 - pineapple cake; 12 - sweet vermicelli; 13- low protein bread; 14 - low protein yogurt. 
Linoleic acid (C18:2n-6) was the major polyunsaturated fatty acid (PUFA). The highest amount (49\%) was found in vegetables patties (recipe 9). Corn oil, a rich source of linoleic acid (C18:2n-6), was the major fat contributor in this recipe.

Besides finding low relative percentages of $n-3$ PUFA, ranging from $0.33 \%$ in pineapple cake (recipe 11 ) to $1.50 \%$ in carrot soup (recipe 2), we have also found low $n-3 / n-6$ ratios $(<0.26)$ in all recipes. This strengthens the need for an adequate $n-3$ PUFA supplementation, especially if there is poor compliance of the amino acid mixtures by patients.

Vitamin $E$ includes eight chemically distinct molecules: $\alpha-, \beta-, \gamma-$ and $\delta$-tocopherol and $\alpha-, \beta-, \gamma$ - and $\delta$-tocotrienol, sharing structural homology. $\alpha$-Tocopherol is the most studied isoform of natural vitamin $\mathrm{E}$, as it appears to have further biological functions than just its antioxidant activity, showing specific interactions with enzymes, structural proteins, lipids and transcription factors. Like tocopherols, tocotrienols also exhibit antioxidant activity. Recently, more attention has been given to this second group of compounds, since there is some evidence that they may have superior biological properties and that their anti-inflammatory and antioxidant activities may prevent cancer, diabetes, cardiovascular and neurodegenerative diseases. ${ }^{24-26}$ Vitamin $\mathrm{E}$ exists in various forms in most edible oils, the major source of its intake. ${ }^{25,27}$

Total tocopherol and tocotrienol contents were lower than $1 \mathrm{mg} \mathrm{g}^{-1}$ fat for all dishes. Data expressed in $\mathrm{mg}$ per $100 \mathrm{~g}$ of cooked sample are presented in Table 3. a-Tocopherol was present in all recipes. The second most prevailing vitamer was $\mathrm{Y}$-tocopherol, followed by $\mathrm{Y}$-tocotrienol. In turn, $\delta$-tocotrienol was the least representative vitamer. Tocopherol and tocotrienol contents were higher in dishes with considerable amounts of fat as an ingredient, which is the case of onion pie and biscuits cake (recipes 7 and 10, respectively); in those which were fried, namely, vegetable croquettes and vegetable patties (recipes 8, 9 and 10, in that order); and in sweet vermicelli (recipe 12). In this last case, $\boldsymbol{\alpha}$-tocopherol was the main vitamer. This may be possibly associated with the low-protein food milk substitute's composition, which is produced from cows' milk cream, an appreciable source of $\alpha$-tocopherol. ${ }^{28}$ Some recipes $(7,10$, and 11) containing vegetal margarine exhibited the 8 vitamers simultaneously, reflecting the vitamin E profile of this ingredient. ${ }^{25}$ Dietary Recommended Intake (DRI) for vitamin $\mathrm{E}$, for adults, is about $15 \mathrm{mg}$ per day. ${ }^{29}$ As PKU patients may be at risk for its deficiency, the selection of good quality fats to prepare and cook foods is important in order to improve their vitamin $\mathrm{E}$ intake and, consequently, promote a better antioxidant protection. Regarding the recipes in the present work, it would be possible to attain this daily total amount of vitamin $\mathrm{E}$, ensuring appropriate combinations of foods.

A well balanced diet ensures an adequate intake of micronutrients, such as minerals and trace elements. However, these undergo significant changes in food, mainly due to processing or manufacturing. For this reason, processed products are often fortified with some important nutrients, to prevent nutritional deficiencies even in the general population. Decreased reserves of $\mathrm{Fe}$ and $\mathrm{Zn}$ are a common feature associated with vegetarian diets. ${ }^{30,31}$ The PKU diet is similar to a vegan diet, but taken to the extreme. As mentioned earlier, micronutrient imbalance in PKU patients is common and a challenging subject when planning the diet.

$\mathrm{Fe}$ is an extremely important trace element, essential for the formation of hemoglobin and myoglobin, which carry oxygen in the blood. Moreover, it is part of many proteins and enzymes in the organism. ${ }^{32}$ Animal origin foods contain heme $\mathrm{Fe}$, the most bioavailable form of Fe. Plant origin foods, in contrast, contain non-heme $\mathrm{Fe}$, whose bioavailability may be affected by absorption inhibitors, including phytates, calcium, and fiber, as well as polyphenols. However, there are ways to significantly improve the absorption of Fe by combining foods rich in vitamin $\mathrm{C}$ and other organic acids, commonly found in fruits and vegetables. ${ }^{12,33}$

Zinc is one of the most abundant nutritionally essential elements in the human body. It is important for the structure

Table 3 Tocopherol and tocotrienol composition (mg per $100 \mathrm{~g}$ cooked sample)

\begin{tabular}{|c|c|c|c|c|c|c|c|c|}
\hline & $\alpha-T F$ & $\alpha-T R$ & $\beta-\mathrm{TF}$ & $\beta-\mathrm{TR}$ & $\mathrm{Y}$-TF & $Y$-TR & $\delta-\mathrm{TF}$ & $\delta-\mathrm{TR}$ \\
\hline 1 & $0.04 \pm 0.00$ & $0.04 \pm 0.00$ & $0.03 \pm 0.00$ & - & $0.04 \pm 0.00$ & $0.01 \pm 0.00$ & - & - \\
\hline 2 & $0.08 \pm 0.01$ & $0.08 \pm 0.03$ & - & - & $0.09 \pm 0.03$ & - & - & - \\
\hline 3 & $0.79 \pm 0.12$ & - & - & - & $0.35 \pm 0.03$ & $0.07 \pm 0.00$ & - & - \\
\hline 4 & $0.27 \pm 0.03$ & $0.37 \pm 0.06$ & $0.20 \pm 0.03$ & $0.03 \pm 0.00$ & $0.41 \pm 0.07$ & - & - & - \\
\hline 5 & $0.07 \pm 0.00$ & - & - & - & - & - & - & - \\
\hline 6 & $0.10 \pm 0.00$ & $0.14 \pm 0.01$ & $0.08 \pm 0.00$ & $0.01 \pm 0.00$ & - & $0.02 \pm 0.00$ & $0.01 \pm 0.00$ & - \\
\hline 7 & $1.96 \pm 0.17$ & $1.08 \pm 0.04$ & $0.47 \pm 0.01$ & $0.05 \pm 0.01$ & $1.40 \pm 0.01$ & $2.67 \pm 0.45$ & $0.03 \pm 0.01$ & $0.21 \pm 0.01$ \\
\hline 8 & $1.87 \pm 0.21$ & $1.19 \pm 0.06$ & - & - & $1.16 \pm 0.06$ & $0.14 \pm 0.03$ & - & - \\
\hline 9 & $2.15 \pm 0.19$ & $0.71 \pm 0.03$ & $0.37 \pm 0.01$ & - & $6.26 \pm 0.48$ & $0.41 \pm 0.01$ & $0.19 \pm 0.03$ & - \\
\hline 10 & $1.89 \pm 0.32$ & $2.19 \pm 0.32$ & $0.60 \pm 0.05$ & $0.10 \pm 0.00$ & $1.22 \pm 0.09$ & $5.79 \pm 0.69$ & $0.08 \pm 0.01$ & $0.42 \pm 0.04$ \\
\hline 11 & $0.85 \pm 0.08$ & $0.46 \pm 0.00$ & $0.21 \pm 0.01$ & $0.02 \pm 0.00$ & $0.41 \pm 0.01$ & $0.99 \pm 0.12$ & $0.02 \pm 0.00$ & $0.03 \pm 0.01$ \\
\hline 12 & $0.32 \pm 0.04$ & - & - & - & $0.10 \pm 0.04$ & $0.02 \pm 0.00$ & - & - \\
\hline 13 & $0.22 \pm 0.00$ & - & $0.06 \pm 0.00$ & - & $0.03 \pm 0.00$ & $0.04-0.00$ & - & - \\
\hline 14 & $0.11 \pm 0.00$ & $0.14 \pm 0.00$ & - & - & - & - & - & - \\
\hline
\end{tabular}

Values are the means of triplicate analysis. 1 - green beans soup; 2 - carrot soup; 3 - pasta with vegetables sauce; 4 - roast potatoes with vegetables; 5 - stuffed potato; 6 - vegetables pie; 7 - onion pie; 8 - mushrooms croquettes; 9 - vegetables patties; 10 - biscuits cake; 11 - pineapple cake; 12 - sweet vermicelli; 13 - low protein bread; 14 - low protein yogurt. 
and function of a large number of macromolecules and for over 300 enzymatic reactions, playing also an important role in cell growth, wound healing and proper functioning of the immune and nervous systems. ${ }^{34}$ Foods of animal origin are also excellent sources of $\mathrm{Zn}$. There are also vegetable sources of $\mathrm{Zn}$, namely, legumes, whole grain pasta, wheat germ, fortified cereals and nuts. However, the majority are considered to be forbidden foods for PKU individuals as they are sources of natural protein. ${ }^{31}$

In the analysed recipes, Fe contents varied between $0.1 \mathrm{mg}$ per $100 \mathrm{~g}$ (sweet vermicelli, 12) and $3.9 \mathrm{mg}$ per $100 \mathrm{~g}$ (onion pie, 7). Concerning $\mathrm{Zn}$ contents, all recipes presented lower than $0.5 \mathrm{mg}$ per $100 \mathrm{~g}^{-1}$ amounts.

As can be observed in Fig. 1, dishes with considerable amounts of special low-protein flour were those that presented higher levels of Fe (7 (3.9 mg per $100 \mathrm{~g}), 9(5.5 \mathrm{mg}$ per $100 \mathrm{~g})$, $11(1.1 \mathrm{mg}$ per $100 \mathrm{~g})$ and $13(2.8 \mathrm{mg}$ per $100 \mathrm{~g})$. However, it was not possible to relate $\mathrm{Zn}$ contents with a particular ingredient.

Fig. 2 and 3 represent the differences between estimated contents and the corresponding analytical data obtained. Most of the food composition databases (FCD) overestimated $\mathrm{Fe}$ contents in the majority of recipes at about 0.02 to $1.56 \mathrm{mg}$. However, the opposite situation was observed in 3 recipes, where the three FCDs underestimated Fe levels at about 0.01 to $1.75 \mathrm{mg}$. Concerning Zn (Fig. 3), the three FCDs presented overestimated contents in the majority of recipes at about 0.01 to $0.48 \mathrm{mg}$. As in the $\mathrm{Fe}$ case, $\mathrm{Zn}$ was also underestimated in some recipes in amounts ranging from 0.01 to $0.18 \mathrm{mg}$.

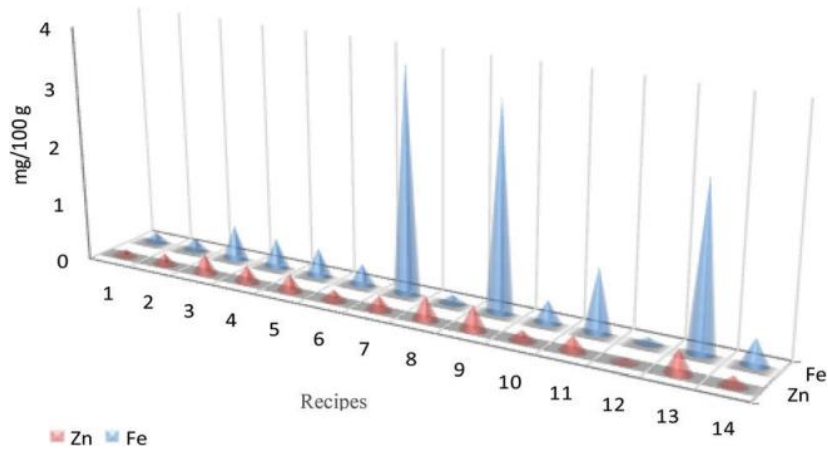

Fig. 1 Iron (Fe) and zinc ( $\mathrm{Zn}$ ) composition of the dishes in mg per $100 \mathrm{~g}$ of the edible part. Values are the means of triplicate analysis. Recipes: 1 - green beans soup; 2 - carrot soup; 3 - pasta with vegetables sauce; 4 - roast potatoes with vegetables; 5 - stuffed potato; 6 - vegetables pie; 7 - onion pie; 8 - mushrooms croquettes; 9 - vegetables patties; 10 biscuits cake; 11 - pineapple cake; 12 - sweet vermicelli; 13 - low protein bread; 14 - low protein yogurt.

For both $\mathrm{Fe}$ and $\mathrm{Zn}$, the analytical results were compared to estimate contents based on the three FCDs. In what concerns Fe, FCDs gave generally similar information conducting overor underestimated amounts in the same direction, and in the same order of magnitude, for each recipe. On the other hand, this was not so linear for $\mathrm{Zn}$ composition, as the slight variations within some recipes were sometimes overestimated, and in others, underestimated. These slight deviations are unquestionably related with several different factors such as natural variability of the nutritional composition of foods, variability

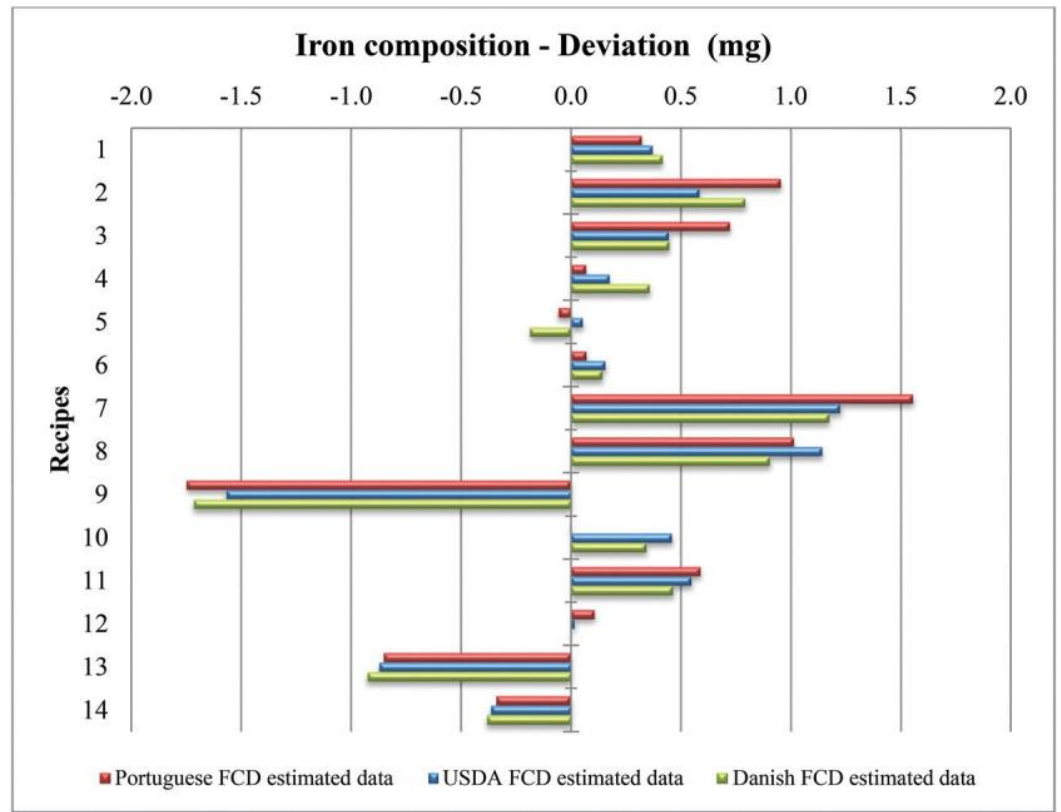

Fig. 2 Deviations in iron $(\mathrm{Fe})$ composition of the dishes $(\mathrm{mg})$ based on the comparison of analytical results and estimated data from Portuguese, USA and Denmark food composition databases (FCDs). Recipes: 1 - green beans soup; 2 - carrot soup; 3 - pasta with vegetables sauce; 4 - roast potatoes with vegetables; 5 - stuffed potato; 6 - vegetables pie; 7 - onion pie; 8 - mushrooms croquettes; 9 - vegetables patties; 10 - biscuits cake; 11 - pineapple cake; 12 - sweet vermicelli; 13 - low protein bread; 14 - low protein yogurt. 


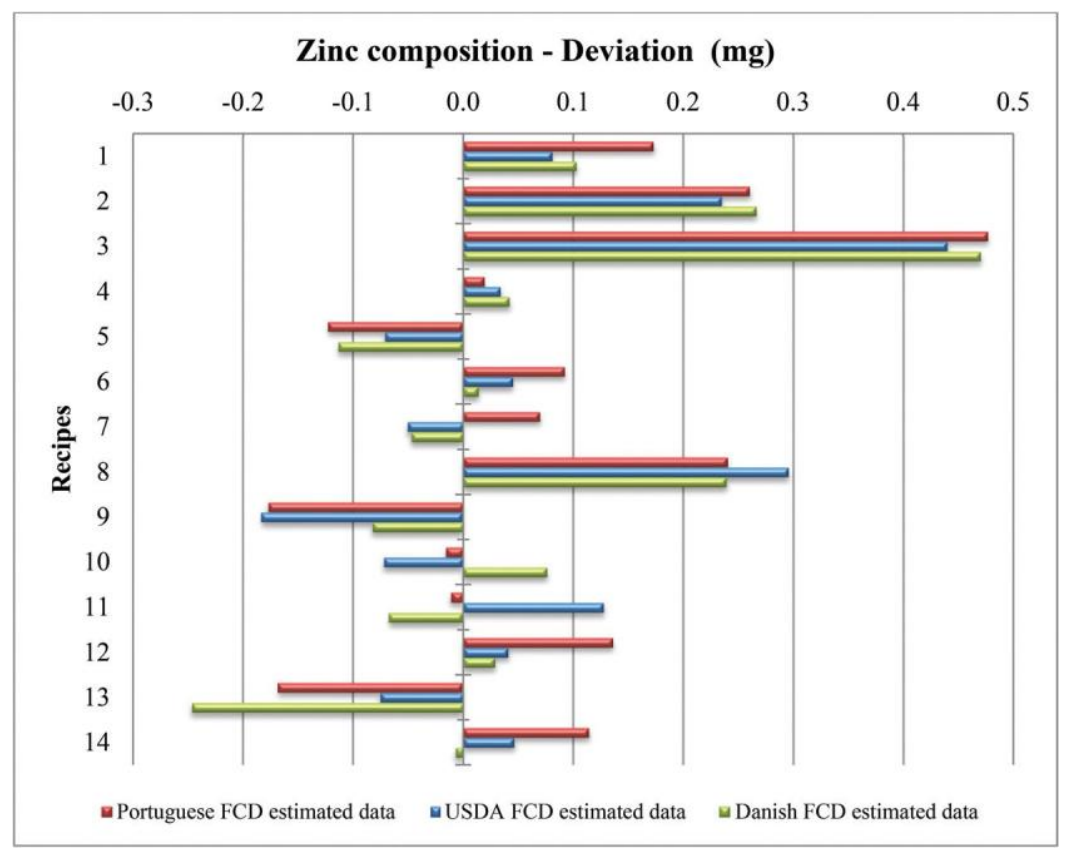

Fig. 3 Deviations in zinc $(\mathrm{Zn})$ composition of the dishes $(\mathrm{mg})$ based on the comparison of analytical results and estimated data from Portuguese, USA and Denmark food composition databases (FCDs). Recipes: 1 - green beans soup; 2 - carrot soup; 3 - pasta with vegetables sauce; 4 - roast potatoes with vegetables; 5 - stuffed potato; 6 - vegetables pie; 7 - onion pie; 8 - mushrooms croquettes; 9 - vegetables patties; 10 - biscuits cake; 11 - pineapple cake; 12 - sweet vermicelli; 13 - low protein bread; 14 - low protein yogurt.

within species, the effect of the cooking methods itself, and the methodology of sample analysis, among others.

For healthy individuals these deviations are not relevant. Nevertheless, in clinical situations requiring severe food restrictions, this is of great significance. Diets based on FCD should be carefully planned (especially regarding micronutrient composition), analyzed and dynamically adjusted whenever required. It is of utmost importance to monitor patients' nutritional status and, if needed, supplementation should always be considered as part of the dietary treatment.

DRI for male and female healthy adults is 8 and $18 \mathrm{mg}$ per day for $\mathrm{Fe}$ and 11 and $9 \mathrm{mg}$ per day for $\mathrm{Zn}$, respectively. ${ }^{35} \mathrm{Con}$ sidering the bioavailability of the trace elements in plant origin foodstuffs, a periodical assessment of individuals' nutritional status is important to guarantee balanced intakes.

\section{Experimental}

Standards and reagents

The fatty acid methyl ester standard mixture (FAME 37) was acquired from Supelco (Bellefonte, PA, USA). Boron trifluoride was from Sigma-Aldrich (Steinheim, Germany). Tocopherols $(\alpha, \beta, y$ and $\delta)$ and tocotrienols $(\alpha, \beta, \gamma$ and $\delta)$ were purchased from Calbiochem (La Jolla, California, USA) and tocol was obtained from Matreya Inc. (Pennsylvania, USA). Butylated hydroxytoluene (BHT) was from Aldrich (Madrid, Spain), High Performance Liquid Chromatography (HPLC) grade acetonitrile and 1,4-dioxane were from Fluka (Madrid, Spain) and HPLC grade $n$-hexane was from Merck (Darmstadt, Germany).
Cesium chloride $(\mathrm{CsCl})$ and nitric acid $\left(\mathrm{HNO}_{3}\right)$ were p.a. quality from Panreac $\AA$ (Barcelona, Spain). Ultrapure water from a Simplicity 185 system (resistivity $18.2 \mathrm{M} \Omega \mathrm{cm}$; Millipore, Belford, USA) was used for the preparation of samples and standards. For iron (Fe) and zinc ( $\mathrm{Zn})$ determination, stock solutions (1000 mg $1^{-1}$; Panreac, Barcelona, Spain) were used.

Samples and sample preparation

Recipe books specifically planned for PKU patients ${ }^{36,37}$ were used to select 14 recipes, including soups $(n=2)$, main courses $(n=7)$, desserts $(n=3)$ and other daily basic foods $(n=2)$. Ingredients of current use were acquired from local supermarkets. The Center of Medical Genetics Doutor Jacinto de Magalhães (Porto, Portugal) kindly provided dietetic low protein and low-Phe products.

Table 1 presents the list of the recipes, types and main ingredients of low protein and restricted Phe dishes selected and analyzed in this study.

Following the respective instructions, all recipes were prepared and cooked in triplicate using domestic scale utensils and equipments. Samples were then homogenized (Classical A320R1, Moulinex, France) and immediately used for lipid extraction. The remaining was kept at $-20{ }^{\circ} \mathrm{C}$ until mineral quantification.

Lipid profile analysis

Lipids were extracted following the Soxhlet procedure with petroleum ether for $3.5 \mathrm{~h}^{38}$ Then, the fatty acid (FA) profile and tocopherol and tocotrienol contents were determined. 
Fatty acid profile

Fatty acids were determined as methyl esters (FAME), prepared by acid-catalysed transmethylation of total lipids using boron trifluoride methanol according to Shantha and Ackman. ${ }^{39}$ These were then analysed by gas chromatography with flame ionization detection in a GC-2010 Shimadzu (Shimadzu Corporation, Tokyo, Japan), according to Fernandes and colleagues. ${ }^{40}$ A CPSil 88 fused silica capillary column (Varian, Middelburg, The Netherlands; $50 \mathrm{~m} \times 0.25 \mathrm{~mm}$ internal diameter, film thickness $0.19 \mu \mathrm{m}$ ) was used for the FAME separation using helium as the carrier gas $(120 \mathrm{kPa})$ and a temperature gradient program $\left(120^{\circ} \mathrm{C}\right.$ for $5 \mathrm{~min}$, increasing to $220{ }^{\circ} \mathrm{C}$ at $3{ }^{\circ} \mathrm{C} \mathrm{min}^{-1}$ and held at $220^{\circ} \mathrm{C}$ for $10 \mathrm{~min}$ ). Injector and detector temperatures were $250{ }^{\circ} \mathrm{C}$ and $270{ }^{\circ} \mathrm{C}$, respectively. A $1.0 \mu \mathrm{l}$ injection volume and a split ratio of $1: 50$ were used. Triplicate assays were performed, each one injected in duplicate. Data were analyzed using the GC Solution software (version 2.30, Shimadzu Corporation, Tokyo, Japan). FAMEs were identified by comparison with standard mixtures (FAME 37, Supelco, Bellefonte, PA, USA) and expressed as relative percentage composition (\%) of the individual FAMEs in the chromatogram. Analyses were performed in triplicate and results are presented in Table 2 .

\section{Tocopherol and tocotrienol contents}

To quantify tocopherols and tocotrienols, fat obtained as previously mentioned was prepared based on the ISO 9936:2006 standard, ${ }^{41}$ using tocol as an internal standard. Briefly, an accurate solution of oil in $n$-hexane, with tocol, was analyzed by HPLC. The chromatographic analysis was carried out in a HPLC integrated system from Jasco (Japan) equipped with an AS-950 automated injector, a PU-980 pump, an MD910 multiwavelength diode array detector (DAD) and an FP920 fluorescence detector, programmed for excitation at 290 $\mathrm{nm}$ and emission at $330 \mathrm{~nm}$. The chromatographic separation of the compounds was achieved on a normal phase Supelcosil $^{\text {TM }}$ LC-SI $(3 \mu \mathrm{m} ; 75 \times 3.0 \mathrm{~mm}$; Supelco, Bellefonte, PA, USA) according to Alves et $a l^{42}$ Chromatographic data were analyzed using a Borwin-PDA Controller Software (JMBS, France). Analyses were performed in triplicate and results were expressed in mg per $100 \mathrm{~g}$ cooked sample (Table 3).

\section{Iron and zinc contents}

The quantification of $\mathrm{Fe}$ and $\mathrm{Zn}$ in samples was performed according to Santos et $a .^{43}$ in a high-resolution continuum source atomic absorption spectrometer (ContrAA 700, from Analytik Jena, Germany), equipped with a xenon short-arc lamp of $300 \mathrm{~W}$ (XBO 301, GLE, Berlin, Germany) and an AS52s autosampler (Analytik Jena, Germany), after acid digestion in a microwave (MARS-X $1500 \mathrm{~W}$; CEM, Mathews, USA), with pressure and temperature control, using a $100 \mathrm{~mL}$ Teflon ${ }^{\circledR} \mathrm{HP}$ 500 Plus ${ }^{\circledR}$ vessels (CEM Corporation, Matthews, EUA). Briefly, previously homogenized frozen samples were left at room temperature. The equivalent amount of $0.3 \mathrm{~g}$ (dry weight) of each one was weighed into the vessels and dried in the microwave, until constant weight. After cooling, $8 \mathrm{ml}$ of $65 \%$ nitric acid and $2 \mathrm{ml}$ of $30 \%$ peroxide hydrogen were added to the samples and the microwave assisted digestion was carried out for $30 \mathrm{~min}$ at a maximum temperature of $140{ }^{\circ} \mathrm{C}$. The clear solutions were then atomized in air/acetylene oxidising flame (Linde, Portugal) and quantified at 248.327 $(\mathrm{Fe})$ and $213.857 \mathrm{~nm}(\mathrm{Zn})$. Data acquisition and treatment were performed in Aspect CS (1.4.0 version) also from Analytik Jena. Analyses were performed in triplicate and results are expressed as mg per $100 \mathrm{~g}$ of edible sample (Fig. 1).

Food composition databases (FCD)

Analytical results obtained for $\mathrm{Fe}$ and $\mathrm{Zn}$ contents were compared with estimated data from different food composition databases (FCDs) (Fig. 2 and 3). Three FCDs, namely, the Portuguese FCD ${ }^{28}$ the United States Department of Agriculture, National Nutrient Database (USDA), ${ }^{44}$ and the Danish Food Composition Databank, ${ }^{45}$ were selected for comparison purposes.

Statistical analysis

Data were reported as mean \pm standard deviation. Data treatment was carried out with the Microsoft Excel statistical software (Microsoft Office Excel 2003, Microsoft Corp., Redmond, WA).

\section{Conclusions}

The PKU diet is unquestionably a forcibly very restrictive vegan-like prescribed diet. Patients need to follow a lowprotein diet, but still healthily balanced. In this study, it was possible to see that the fatty acid and vitamin $\mathrm{E}$ profiles strongly depend on the different types of fats used to prepare and cook foods. These dishes are poor sources of essential nutrients like Fe, Zn or $n-3$ fatty acids, reinforcing the need for adequate supplementation to cover individual patients' needs. This study can contribute to a more accurate adjustment of PKU diets and supplementation in order to prevent eventual nutritional deficiencies.

We believe that these are important information inputs that can help in finding alternative strategies to successfully select the best ingredient combinations, facilitate the nutritional and dietetic prescription, a good compliance of the diet, as well as a good metabolic control and nutritional status of the patients.

\section{Conflict of interest}

None.

\section{Acknowledgements}

The authors thank SNA - Centro de Genética Médica Doutor Jacinto de Magalhães, CHP EPE (Porto, Portugal) for kindly 
supplying all the dietetic low protein and low-Phe products used in the current study.

Rita C. Alves is grateful to Fundação para a Ciência e a Tecnologia (FCT) for a post-doctoral research grant (SFRH/BPD/ 68883/2010) financed by POPH-QREN - Tipologia 4.1 - Formação Avançada, subsidized by Fundo Social Europeu and Ministério da Ciência, Tecnologia e Ensino Superior. This work received financial support from the European Union (FEDER funds through COMPETE) and National Funds (FCT) through project Pest-C/EQB/LA0006/2013. The work also received financial support from the European Union (FEDER funds) under the framework of QREN through project NORTE-07-0124FEDER-000069.

\section{References}

1 F. J. van Spronsen, Nat. Rev. Endocrinol., 2010, 6, 509-514.

2 S. F. Dobrowolski, C. Heintz, T. Miller, C. Ellingson, C. Ellingson, I. Özer, G. Gökçay, T. Baykal, B. Thöny, M. Demirkol and N. Blau, Mol. Genet. Metab., 2011, 102, 116-121.

3 A. M. Lammardo, M. Robert, J. C. Rocha, M. van Rijn, K. Ahring, A. Bélanger-Quintana, A. MacDonald, K. Dokoupil, H. G. Ozel, P. Goyens and F. Feillet, Mol. Genet. Metab., 2013, 110, S1-S5.

4 M. Giovannini, E. Verduci, E. Salvatici, S. Paci and E. Riva, Nutr. Metab., 2012, 9, 7.

5 A. MacDonald, J. C. Rocha, M. van Rijn and F. Feillet, Mol. Genet. Metab., 2011, 104,S10-S18.

6 J. C. Rocha and M. J. Martins, J. Inherited Metab. Dis., 2012, 35, 381-398.

7 F. Feillet and C. Agostoni, J. Inherited Metab. Dis., 2010, 33, 659-664.

8 E. Weetch and A. MacDonald, J. Hum. Nutr. Diet., 2006, 19, 229-236.

9 H. J. Bremer, A. Anninos and B. Schulz, Eur. J. Pediatr., 1996, 155, S108-S114.

10 A. M. Hvas, E. Nexo and J. B. Nielsen, J. Inherited Metab. Dis., 2006, 29, 47-53.

11 J. H. Walter, Mol. Genet. Metab., 2011, 104 Suppl., S52-S54.

12 W. J. Craig and A. R. Mangels, J. Am. Diet. Assoc., 2009, 109, 1266-1282.

13 F. J. van Spronsen and P. Burgard, J. Inherited Metab. Dis., 2008, 31, 673-679.

14 M. Demirkol, M. Gizewska, M. Giovannini and J. Walter, Mol. Genet. Metab., 2011, 104, S31-S39.

15 A. Bélanger-Quintana, A. Burlina, C. O. Harding and A. C. Muntau, Mol. Genet. Metab., 2011, 104, S19-S25.

16 F. B. Pimentel, R. C. Alves, A. S. G. Costa, T. J. R. Fernandes, D. Torres, M. F. Almeida and M. B. P. P. Oliveira, LWT - Food Sci. Technol., 2014, 57, 283-289.

17 F. B. Pimentel, R. C. Alves, A. S. G. Costa, D. Torres, M. F. Almeida and M. B. P. P. Oliveira, Food Chem., 2014, 149, 144-150.

18 J. W. Lampe, Am. J. Clin. Nutr., 2003, 78, 579S-583S.
19 B. Koletzko, R. Uauy, A. Palou, F. Kok, G. Hornstra, A. Eilander, D. Moretti, S. Osendarp, P. Zock and S. Innis, Brit. J. Nutr., 2010, 103, 923-928.

20 P. R. Burghardt, E. S. Kemmerer, B. J. Buck, A. J. Osetek, C. Yan, L. G. Koch, S. L. Britton and S. J. Evans, Cellulose (Fiber), 2010, 47, 47.40.

21 S. L. Goodstine, T. Zheng, T. R. Holford, B. A. Ward, D. Carter, P. H. Owens and S. T. Mayne, J Nutr, 2003, 133, 1409-1414.

22 B. Koletzko, T. Sauerwald, H. Demmelmair, M. Herzog, U. von Schenck, H. Böhles, U. Wendel and J. Seidel, J. Inherited Metab. Dis., 2007, 30, 326-332.

23 J. Brát and J. Pokorný, J. Food Compost Anal., 2000, 13, 337343.

24 C. K. Sen, S. Khanna and S. Roy, Mol. Aspects Med., 2007, 28, 692-728.

25 H. Schwartz, V. Ollilainen, V. Piironen and A.-M. Lampi, J. Food Compost Anal., 2008, 21, 152-161.

26 B. B. Aggarwal, C. Sundaram, S. Prasad and R. Kannappan, Biochem. Pharmacol., 2010, 80, 1613-1631.

27 P. Gama, S. Casal, B. Oliveira and M. A. Ferreira, J. Liq. Chromatogr. Relat. Technol., 2000, 23, 3011-3022.

28 Instituto Nacional de Saúde Doutor Ricardo Jorge (INSA). Tabela de Composição dos Alimentos - INSA, 2006. URL: http://www.insa.pt/sites/INSA/Portugues/Areas Cientificas/ AlimentNutricao/AplicaoesOnline/TabelaAlimentos/PesquisaOnline/Paginas/PorPalavraChave.aspx. Accessed 01.08.2012.

29 Institute of Medicine. Food and Nutrition Board. Dietary Reference Intakes for Vitamin C, Vitamin E, Selenium, and Carotenoids, The National Academies Press, Washington, DC, 2000 .

30 N. Martínez-Navarrete, M. M. Camacho, J. MartínezLahuerta, J. Martínez-Monzó and P. Fito, Food Res. Int., 2002, 35, 225-231.

31 J. R. Hunt, Am. J. Clin. Nutr., 2003, 78, 633s-639s.

32 W. Herrmann and J. Geisel, Clin. Chim. Acta, 2002, 326, 4759.

33 M. Robert, J. C. Rocha, M. van Rijn, K. Ahring, A. BélangerQuintana, A. MacDonald, K. Dokoupil, H. G. Ozel, A. M. Lammardo, P. Goyens and F. Feillet, Mol. Genet. Metab., 2013, 110,S6-S17.

34 H. Tapiero and K. D. Tew, Biomed. Pharmacother., 2003, 57, 399-411.

35 Institute of Medicine. Dietary Reference Intakes for Vitamin A, Vitamin K, Arsenic, Boron, Chromium, Copper, Iodine, Iron, Manganese, Molybdenum, Nickel, Silicon, Vanadium, and Zinc, The National Academies Press, 2001.

36 M.F. Almeida, PKU Comer bem... sem fazer mal., Instituto de Genética Médica Doutor Jacinto de Magalhães Publisher and Distributor, Porto, Portugal, 1995, vol. 1.

37 M. F. Almeida, PKU Comer bem... sem fazer mal., Instituto de Genética Médica Doutor Jacinto de Magalhães Publisher and Distributor, Porto: Porto, Portugal, 2001, vol. 2.

38 Official Methods of Analysis of AOAC International. in Fat (crude) 920.39 c, W. Horwitz. AOAC, Gaithersburg, USA, 17th edn, 2000. 
39 N. C. Shantha and R. G. Ackman, J. Chromatogr., B: Biomed. Sci. Appl., 1990, 533, 1-10.

40 T. J. R. Fernandes, R. C. Alves, T. Souza, J. M. G. Silva, M. Castro-Cunha, L. M. P. Valente and M. B. P. P. Oliveira, Food Chem., 2012, 134, 1337-1342.

41 ISO 9936:2006, Animal and Vegetable Fats and Oils. Determination of Tocopherol and Tocotrienol Contents by HighPerformance Liquid Chromatography, British Standards Institute Standards, 2006.

42 R. C. Alves, S. Casal and M. B. P. P. Oliveira, Food Sci. Technol. Int., 2009, 15, 57-63.
43 J. Santos, M. T. Oliva-Teles, C. Delerue-Matos and M. B. P. P. Oliveira, Food Chem., 2014, 151, 311-316.

44 United States Department of Agriculture and A. R. Service, USDA National Nutrient Database for Standard Reference, Release 24. Nutrient Data Laboratory Home Page, http:// www.ars.usda.gov/ba/bhnrc/ndl, Accessed 2012-08-01.

45 E. Saxholt, A.T. Christensen, A. Møller, H.B. Hartkopp, K. Hess Ygil and O.H. Hels, Danish Food Composition Databank, revision 7, Department of Nutrition, National Food Institute, Technical University of Denmark, 2008. URL: http:// www.foodcomp.dk/v7/fcdb_search.asp. Accessed in 01.08.2012. 